\title{
EVOLUTION OF RESEARCH ON RECALCITRANT SEEDS
}

\author{
C.J. BARBEDO; D.A.C. BILIA
}

Instituto de Botânica/Seção de Sementes e Melhoramento Vegetal, C.P. 4005, CEP: 01061-970 - São Paulo, SP, Brasil.

ABSTRACT: Some comments about seeds that show sensitivity to desiccation and short viability period, called recalcitrants, were made. Further studies showed that there was a gradient of sensitivity to desiccation and an intermediate class was proposed. The research demonstrated different factors related to desiccation tolerance such as $\mathrm{ABA}$, proteins and sugars. It was analyzed the research of recalcitrant seeds in Brazil, that started around 1950 and nowadays the major aspects studied are recalcitrant seeds identification, seed low temperature and drying tolerance, storage capacity under different rooms and packages, chemical composition and viability during storage, fungicide treatment efficiency on seed conservation.

Key Words: seed, recalcitrant, desiccation tolerance, Brazil

\section{EVOLUÇÃO DA PESQUISA EM SEMENTES RECALCITRANTES}

RESUMO: São apresentadas considerações sobre espécies cujas sementes apresentam sensibilidade à dessecação e reduzido período de viabilidade, inicialmente denominadas recalcitrantes. Estudos posteriores demonstraram haver gradiente de sensibilidade à dessecação e uma categoria intermediária foi proposta. As pesquisas têm relatado diversos fatores relacionados à tolerância à dessecação, tais como ABA, proteínas e açúcares. São reportados estudos com sementes recalcitrantes no Brasil, que se iniciaram na década de 50 e, atualmente, estão dirigidos a identificação, tolerância à secagem e à baixa temperatura, capacidade de armazenamento, relação entre composição química e viabilidade e efeito de tratamentos fungicidas para a conservação durante o armazenamento.

Descritores: semente, recalcitrante, tolerância à dessecação, Brasil

\section{INTRODUCTION}

Some particular characteristics of orthodox seeds probably are co-responsible for the beginning of agriculture, leading to mankind to sow with seeds at different times of the seed production. The desiccation tolerance of orthodox seeds was a useful characteristic. Man could store seeds during long periods to hard days. In these seeds, the natural drying during final development was usual and, during long time, neither physiological either biochemical studies on this subject have been performed. Otherwise, another group of seeds, called recalcitrant, are more sensitive to desiccation and cannot be stored for long periods.

This different seed behavior is a consequence of natural processing selection, at different weather conditions. The seedlings of orthodox seeds, to a great extent cultivated species, probably needed to survive the adverse environmental times. Those that germinated immediately after shedding did not survive so that seeds which produced seedlings during suitable environmental conditions, were selected.
Furthermore, it is likely that the lower water content of these seeds limited the germination and prevented from microorganism deterioration.

On the other hand, recalcitrant seeds were probably selected in a habitat distinct from at which orthodox seeds were selected. This habitat permitted seedling development during all year. The seed drying at this environment would be another limiting factor for germination: additional water dependence. Thus, orthodox seeds, which did not germinate immediately, probably did not succeed due to competition with other species and, were stored dried in soil, deteriorated or germinated under poor and shadowy conditions. In both cases, the perpetuation of this species would be unsatisfactory.

But what is recalcitrant seed? Roberts proposed the term recalcitrant seed in 1973 and since then many reviews have been published around the world about this. Nonetheless, the classical distinction between orthodox and recalcitrant seeds is under attack, because the noun recalcitrant cannot be used correctly. The distinction of these therms was firstly 
a general one, taking into account only desiccation tolerance and lower longevity. Consequently, different seeds were in the same class. Currently, some researchers are proposing a new classification, which is based on the existence of different grades of tolerance to desiccation.

There is a current concern to distinguish nonorthodox seeds describing some features such as: a) species natural habitat; b) longevity during storage, and the stored conditions for this; c) medium water content in which seed viability is $50 \%$; d) chilling sensibility; e) seed dormancy (Berjak \& Pammenter, 1994).

Otherwise, some characteristics are common to several recalcitrant seeds, such as immediate germination after shedding, low longevity and desiccation intolerance. Desiccation intolerance is probably better for this kind of distinction. That is the reason why this factor must be studied deeply.

\section{DESICCATION TOLERANCE}

It has been proposed by several authors that abscisic acid (ABA) is probably related (directly or indirectly) to seed desiccation tolerance. Furthermore, some experimental evidence shows the activity of exogenous ABA, although a relationship with desiccation tolerance has not been observed when the levels of endogenous ABA are followed.

Carrot somatic embryos treated with ABA germinated well after desiccation and rehydration; the opposite occurred with non-treated ones that died after desiccation (Iida et al., 1992). Avicennia marina seeds, which are classified as recalcitrant, have lower ABA content than orthodox seeds and pattern of content of other growth regulators (Farrant et al., 1993). ABA can influence indirectly certain physiological and biochemical events, thus promoting seed water stress. Amongst them are the production of mRNAs and proteins (Bartels et al., 1988; Mundy \& Chua, 1989; Bruggink \& Toorn, 1995) and soluble carbohydrates content related with desiccation process (Tetteroo et al., 1994).

Corn seed produce some proteins that occur only during developmental phases when there is desiccation tolerance (Bochicchio et al., 1988). Likewise, soybean seed produces polypeptides related to water stress (Rosenberg \& Rinne, 1988). These polypeptides are like LEA (Late Embryogenesis Abundant) protein cotton seeds (Galau et al., 1986) and Ranunculus sceleraturs seeds (Wechsberg et al., 1994). Some protein from barley seed is enhanced during the process that leads this seed to desiccation tolerance (Bartels et al., 1988).

However, the absence of proteins related with desiccation is not the unique factor of the lack of desiccation tolerance of recalcitrant seeds as indicate experiments performed by Blacken et al. (1991 and 1992), Bradford \& Chandler (1992) and Gee et al. (1994), with seeds tolerant and intolerant to desiccation. Some seeds intolerant to desiccation which have desiccation-protein like orthodox seeds, do not survive after drying. It is thought that these LEA proteins have fundamental function in tolerance desiccation process.

Some sugars like sucrose and other oligosaccharides are present in desiccation tolerance process in corn, soybean, and pea seeds during the beginning of germination (Koster \& Leopold, 1988). After these oligosaccharides were removed, the desiccation tolerance disappears.

Corn seeds during germination have high raffinose and sucrose contents and no glucose and fructose. The opposite occurs during the development of the desiccation intolerance (Leprince et al., 1992); the same being observed in alfalfa and carrot somatic embryos (Tetteroo et al., 1994) and in cauliflower seeds (Hoekstra et al., 1994).

The ability of desiccation tolerance in some seeds may originate from mechanisms of avoidance of cellular destruction during water losses. When a non-tolerant desiccation cell dehydrates, its solutes can be more concentrated (probably increasing the destructive chemical reactions), some solutes can crystallize (modifying ionic resistance and $\mathrm{pH}$ intracellular solution), proteins begins denaturing and the membranes begins rupturing (with compartmentalization losses). The presence of great amounts of soluble sugars within a cell can prevent from harmful damages of desiccation building up hydrogen links and, then, substituting water in preservation the water structures orientation, when hydrated (Crowe et al., 1988, apud Koster, 1991).

This ability probably derives from the capacity to reach glassy state at room temperature (Koster, 1991). This state depends on the ratio sucrose:raffinose, in special to prevent from crystallization. The combination among sugars present in desiccation tolerance cells affords glassy state reaching at temperatures higher than $0^{\circ} \mathrm{C}$ and lower than $0^{\circ} \mathrm{C}$ in non-desiccation tolerant ones. The glassy state of water, function its high viscosity, would delay solutes crystallization and total 
dehydration. Molecular mobility inhibition prevents denaturation and undesirable biochemical reactions, guaranteeing the survival of desiccated seeds (Willians \& Leopold, 1989)

\section{RECALCITRANT SEED CONSERVATION}

Current methods and perspectives: Current methods to conservation and storage recalcitrant seeds are based upon high water content maintenance. There is a threshold of minimal value ofwater content, below which there is damage to germination of recalcitrant seeds. At high water contents, there are many metabolic reactions and microorganism development, which are preventing by reducing the temperature. Thus the water content of recalcitrant seeds and storage temperature must be reduced until near the minimum critical water content. We spite of all this, the current methods to conservation of recalcitrant seeds are not fully efficient yet.

Great progress in this area was impaired by the work by Farrant et al. (1986) and Pammenter et al. (1994). They propose that water stress can occur in hydrated stored recalcitrant seed, because recalcitrant seed do not stop growing at the end of its formation and maturation, they only reduce their levels of metabolism. Thus, there is water stress in hydrated stored recalcitrant seed resulted from enhancement of cellular division and expansion.

Those are the reasons why recalcitrant seed conservation methods similar to orthodox ones for longer periods are not successful, especially dryness. Recalcitrant seed conservation might paralyze embryo growth. The supply of water has to be maintained to prevent from dehydration, below the minimum critical water content. There is no guarantee that every known factor related with recalcitrant seed desiccation tolerance can be applied artificially to these seeds. This is an area with many unanswered questions.

Research with recalcitrant seed at Brazil: Castro \& Krug performed research in this area at 50's, with Inga edulis and I. striata seeds. They observed these seeds did not rest at end of maturation. Like orthodox seeds, they could germinate within fruit and lose germination capacity after desiccation. In their descriptions there were two essential characteristics of recalcitrant seeds: viviparity and desiccation intolerance.
At 1961 Bacchi observed further characteristics of Inga edulis like minimum critical water content, based in Jones' studies at 1920. In his work seeds began losing vitality at $35 \%$ water content, first national description about this concept. Bacchi described another important characteristic of recalcitrant seeds: short longevity.

At 60's and 70's other works were performed with Brazilian species like Araucaria angustifolia, Inga edulis e Theobroma cacao (Prange, 1964; Zink \& Rochelle, 1964). At 70's, there was Ph.D. thesis about Araucaria angustifolia recalcitrant seeds (germination and seedling development).

At 80's and 90's there are many works about seeds of Araucaria angustifolia, Theobroma cacao, Euterpe edulis, Hevea brasiliensis, Virola surinamensis, Myrtaceae family, Inga, Ocotea and Nectandra species, besides species from Amazon Forest and Palmae family in Brazil. The major aspects studied and published by periodic and at scientific meetings, in a quick view, are recalcitrant seed identification, seed low temperature and drying tolerance (and water minimum critical water content establishment), storage capacity under different rooms and packages, relation chemical composition and viability during storage and only with Hevea brasiliensis seeds, fungicide treatment efficiency to seed conservation.

At 1993, there was first Brazilian recalcitrant seed workshop and seed recalcitrant technical committee of Associação Brasileira de Tecnologia de Sementes (ABRATES) - Brazilian Association of Seed Technology was born at VIII Brazilian Seed Congress. This committee had the duty to find researchers who study recalcitrant seeds in Brazil and to produce a newsletter for technical information which also contained event calendars, members participation in these events, post-graduation courses, thesis about this theme, studentships, works and members of this committee.

\section{REFERENCES}

BACCHI, O. Estudos sobre a conservação de sementes: IX - Ingá. Bragantia, v.20, p.805-814, 1961.

BARTELS, D.; SINGH, M.; SALAMINI, F. Onset of desiccation tolerance during development of the barley embryo. Planta, v.175, p.485-492, 1988.

BERJAK, P.; PAMMENTER, N.W. Recalcitrant is not an all-or-nothing situation. Seed Science Research, v.4, p.263-264, 1994. 
BLACKMAN, S.A.; WETTLAUFER, S.H.; OBENDORF, R.L.; LEOPOLD, A.C. Maturation proteins associated with desiccation tolerance in soybean. Plant Physiology, v.96, p.868-874, 1991.

BLACKMAN, S.A.; OBENDORF, R.L.; LEOPOLD, A.C. Maturation proteins and sugars in desiccation tolerance of developing soybean seeds. Plant Physiology, v.100, p.225-230, 1992.

BRADFORD, K.J.; CHANDLER, P.M. Expression of "dehydrin-like" proteins in embryos and seedlings of Zizania palustris and Oryza sativa during dehydration. Plant Physiology, v.99, p.488-494, 1992.

BRUGGINK, T.; TOORN, P. van der. Induction of desiccation tolerance in germinated seeds. Seed Science Research, v.5, p.1-4, 1995 .

BOCHICCHIO, A.; VAZZANA, C.; RASCHI, A.; BARTELS, D.; SALAMINI, F. Effect of desiccation on isolated embryos of maize. Onset of desiccation tolerance during development. Agronomie, v.8, p.29-36, 1988 .

CASTRO, Y.G.P.; KRUG, H.P. Experiências sobre germinação e conservação de sementes de Inga edulis, espécie usada em sombreamento em cafeeiros. Ciência e Cultura, v.3, p.263-264, 1951.

FARRANT, J.M.; PAMMENTER, N.W.; BERJAK, P. The increasing desiccation sensitivity of recalcitrant Avicennia marina seeds with storage time. Physiologia Plantarum, v.67, p.291-298, 1986.

FARRANT, J.M.; BERJAK, P.; CUTTING, J.G.M.; PAMMENTER, N.W. The role of plant growth regulators in the development and germination of the desiccation-sensitive (recalcitrant) seeds of Avicennia marina. Seed Science Research, v.3, p.55-63, 1993.

GALAU, G.A.; HUGHES, D.W.; DURE, L. Abscisic acid induction of cloned cotton late embryogenesisabundant (Lea) mRNAs. Plant Molecular Biology, v.7, p.155-170, 1986.

GEE, O.H.; PROBERT, R.J.; COOMBEER, S.A. 'Dehydrin-like' proteins and desiccation tolerance in seeds. Seed Science Research, v.4, p.135-141, 1994.
HOEKSTRA, F.A.; HAIGH, A.M.; TETTEROO, F.A.A.; ROEKEL, T. van. Changes in soluble sugars in relation to desiccation tolerance in cauliflower seeds. Seed Science Research, v.4, p.143-147, 1994.

IIDA, Y.; WATABE, K.; KAMADA, H.; HARADA, H. Effects of abscisic acid on the induction of desiccation tolerance in carrot somatic embryos. Journal of Plant Physiology, v.140, p.356-360, 1992.

KOSTER, K.L.; LEOPOLD, C. Sugars and desiccation tolerance in seeds. Plant Physiology, v.88, p.829-832, 1988 .

KOSTER, K.L. Glass formation and desiccation tolerance in seeds. Plant Physiology, v.96, p.302-304, 1991.

LEPRINCE, O.; WERF, A. van der; DELTOUR, R.; LAMBERS, H. Respiratory pathways in germinating maize radicles correlated with desiccation tolerance and soluble sugars. Physiologia Plantarum, v.85, p.581-588, 1992.

MUNDY, J.; CHUA, N. Abscisic acid and waterstress induce the expression of a novel rice gene. The EMBO Journal, v.7, p.2279-2268, 1988.

PAMMENTER, N.W.; BERJAK, P.; FARRANT, J.M.; SMITH, M.T.; ROSS, G. Why do stored hydrated recalcitrant seeds die? Seed Science Research, v.4, p.187-191, 1994.

PRANGE, P.W. Estudo de conservação do poder germinativo das sementes de Araucaria angustifolia (Bert.) Oktze. Anuário Brasileiro de Economia Florestal, v.16, p.43-48, 1964.

ROBERTS, E.H. Predicting the storage life of seeds. Seed Science and Technology, v.1, p.499-514, 1973.

ROSENBERG, L.A.; RINNE, R.W. Protein synthesis during natural and precocious soybean seed (Glycine $\max$ [L.] Merr.) maturation. Plant Phisiology, v.87, p.474-478, 1988.

TETTEROO, F.A.A.; BOMAL, C.; HOEKSTRA, F.A.; KARSSEN, C.M. Effect of abscisic acid and slow drying on soluble carbohydrate content in developing embryoids of carrot (Daucus carota L.) and alfalfa (Medicago sativa L.). Seed Science Research, v.4, p.203-210, 1994. 
WILLIANS, R.J.; LEOPOLD, A.C. The glassy state in corn embryos. Plant Physiology, v.89, p.977-981, 1989.

ZINK, E.; ROCHELLE, L.A. Estudos sobre a conservação de sementes. XI - Cacau. Bragantia, v.23, p.111-116, 1964.

Recebido para publicação em 15/07/98 Aceito para publicação em 03/08/98 